\title{
THE INTERNET MIRACLE: THE IMPACT OF INTERNET ACCESS ON HOUSEHOLD SAVING IN INDONESIA
}

\author{
Rahmanda Muhammad Thaariq*, Arif Anindita**, and Hafizha Dea Iftina*** \\ "Corresponding author. Department of Economics and Management. Università di Pisa, Italy. \\ Email: rahmandamt@gmail.com \\ ** Department of Economics and Statistics, Università degli Studi di Napoli Federico II, Italy. \\ **** Department of Economics, National Taiwan University, Taiwan.
}

\begin{abstract}
This study analyzes the impact of internet access on Indonesian households' saving behavior. Using the fifth wave of the Indonesian Family Life Survey dataset, the study shows that internet access has a positive impact on household savings. It further shows that the impact of internet access on household savings depends on whether access is private or public. Private internet access positively impacts both the saving amount and preferences; however, public internet access only positively impacts the saving amount.
\end{abstract}

Keywords: Internet access; Household savings; Asset allocation.

JEL Classifications: D14; E21; O33.

\author{
Article history: \\ Received : October 30, 2020 \\ Revised : January 14, 2021 \\ Accepted : June 07, 2021 \\ Available online : June 30, 2021 \\ https://doi.org/10.21098/bemp.v24i2.1650
}




\section{INTRODUCTION}

This study analyzes the impact of internet access on Indonesian households' saving behavior. Since the Global Financial Inclusion Database was published for the first time in 2011, covering 148 economies and representing around $97 \%$ of the world's population, policymakers in many countries began to utilize internet access as a key strategy to accelerate financial inclusion. For a country like Indonesia, which faces high costs of providing financial services due to its geographical challenges (Setiawan, 2015), internet access is the most affordable solution to expanding financial services to remote areas. Digital technologies, through the internet, are 80 to $90 \%$ less expensive than traditional bank branches for providing financial services (McKinsey Global Institute, 2016).

There is a growing number of studies confirming a positive correlation between internet access and financial inclusion. For instance, Lenka and Barik (2018) and Evans (2018) concluded that an increase in the number of internet and mobile phone users is associated with an increase in financial inclusion. The internet has enhanced education and in turn financial inclusion (Karp and Nash-Stacey, 2015). In the Indonesian case, Ummah et al. (2015) reported that the internet and mobile phones have a significant positive effect on financial inclusion. Furthermore, the government of Indonesia confirmed the importance of the internet in increasing financial inclusion. ${ }^{1}$

Regarding the improvement in the affordability of financial services due to the expansion of internet access, whether this expansion will ultimately impact households' behavior, in terms of household saving allocation, remains unanswered in the existing literature. Frequently, the existing studies discuss household savings in relation to income (Harris, 2002; Finlay and Price, 2015), uncertainty (Kazarosian, 1997; Choi et al., 2017), inflation (Jongwanich, 2010; Cohn and Kolluri, 2003; Grigoli et al., 2018), interest rates (Athukorala and Tsai, 2003; Grigoli et al., 2018), demographics (Horioka and Watanabe, 1997; Braun et al., 2009; Hua and Erreygers, 2019; Lugauer et al., 2019), financial circumstances (Beckmann and Mare, 2017; Steinert et al., 2018), and institutions (Giavazzi and McMahon, 2012; Bebczuk et al., 2015). Until now, there are rare empirical studies comprehensively discussing the effects of internet access on household saving behavior. Our study fills this research gap and thus contributes to the existing literature by linking household saving behavior to internet access in Indonesia. If the expansion of internet access impacts not only financial inclusion, but also the allocation of household savings, then the actual benefits of the expansion of internet access to financial services are greater than our current understanding.

In general, a household's savings are defined as the difference between the household's disposable income and its final consumption expenditure. Household savings, together with corporate and public savings, shape the national savings to fund capital investment, which is a key driver of long-term economic growth. As pointed out by Harrod (1939) and Domar (1946, 1947), the level of economic growth in an economy depends primarily on incremental changes in the capital stock. Since the incremental capital stock equals savings in this "savings gap"

\footnotetext{
1 See https://kominfo.go.id/index.php/content/detail/12297/ojk-sebut-inklusi-keuangan-tembus-63persen-populasi/0/sorotan_media
} 
model, the rate of saving is the key determinant of economic growth (see Harrod, 1939; Domar, 1946, 1947). Besides, Solow (1956) suggested that in the Solow model, when a country's saving rate increases, its capital stock and economic output increase as well.

As compared with developed countries, developing countries like Indonesia need higher economic growth (measured by growth in per capita income) to catch up with the former. Higher economic growth can be achieved through boosting higher credit growth (Calderón and Liu, 2003; Banu, 2013; and Olowofeso et al., 2015; Ho and Iyke, 2018). Consequently, building a relatively large level of national savings is fundamentally important for developing countries. Unfortunately, Indonesia faces challenges in growing its national saving rate. Indonesia's national saving rate has stagnated at around 30\% of its Gross Domestic Product (GDP) since 2012. Furthermore, the composition of the country's household savings has been steadily decreasing and almost completely offset by an increase in the composition of corporate savings at least since 2002. These challenges, in turn, affect the availability of loanable funds for banks, which is reflected in the indicator of third-party funds collected by national banks. Freestone et al. (2011) stated that the rise in the household saving rate, in the form of bank deposits, has improved the resilience of the banking system to a short-term shock in the wholesale funding markets.

This study examines whether internet access increases household savings in Indonesia, in terms of the amount saved and the saving preferences. We use the natural logarithm of the amount saved to capture the amount of savings and the share of savings in total assets to measure saving preferences. The study also examines whether private and public internet access have different impacts on household saving dynamics. We conducted the analysis using the Ordinary Least Squares (OLS) method and micro-level data from the fifth wave of the Indonesian Family Life Survey (IFLS5).

We show that internet access has a positive impact on household savings. We further show that, while public internet access only increases the amount of savings, but not saving preferences, private internet access positively impacts both the amount of savings and the saving preferences. These findings suggest that Indonesian policymakers have more room to increase the amount of national savings as well as third-party funds in banks.

The rest of the paper is structured as follows. Section II briefly discusses the existing literature on household savings and their determinants. Section III explains the data and the methodology. Section IV presents the results on the effect of internet access on household savings. Section V concludes and provides some policy recommendations.

\section{LITERATURE REVIEW}

Various comprehensive empirical studies - both single- and multi-country - have discussed the factors that affect household saving behavior. Income is primarily considered as the main determinant of household savings. For instance, Harris (2002) found that the current income is the most important factor determining household savings in Australia. Finlay and Price (2015) found that households, 
whose current income level is above their permanent income level, tend to save more. Bonham and Wiemer (2013) concluded that the rapid increase in China's national saving rate in the 2000s is largely explained by high rates of GDP growth. Rising incomes were absorbed in higher savings by both households and government due to habit formation (Bonham and Wiemer, 2013). This finding is consistent with Zhuk (2015), who discovered that gross national income has a significant positive effect on household savings in the Ukraine.

Risk (or uncertainty) about future income levels and economic stability is another strong determinant of household savings. Kazarosian (1997) argued that income uncertainty causes individuals to save more as a precautionary move; the size of savings depends on an individual's occupation. Choi et al. (2017) found that the household saving rate largely comes from precautionary motives rather than non-precautionary motives. Households tend to increase their precautionary saving as their income increases, to maintain their targeted wealth-to-income ratio. Employing cross-sectional data of 16 OECD countries, Adema and Pozzi (2015) provided evidence that the household saving ratio is countercyclical and is higher during a recession. Furthermore, Mody et al. (2012) documented an increase in household savings during periods of higher economic uncertainty, primarily when wage rates were likely to be negatively affected.

Inflation is also a determinant of household savings. Jongwanich (2010) explained that inflation could increase the uncertainty regarding the future value of accumulated savings and reduce the rate of return on savings, which in turn encourages households to increase their savings. Using a group of countries, Cohn and Kolluri (2003) and Grigoli et al. (2018) showed that inflation positively affects household savings. In contrast, Samantaraya and Patra (2014) found that inflation has a negative effect on household savings. A possible explanation for this is portfolio adjustments in times of heightened inflationary pressures, as households switch from financial assets to real assets during these times.

In addition to inflation, the interest rate also affects household savings. However, its effect is ambiguous and depends on the magnitude of substitution and income effects. In the context of Taiwan, Athukorala and Tsai (2003) found that the real interest rate had a positive impact on the household saving rate, in which the positive substitution effect offsets the negative income effect. Using a panel data consisting of 165 countries, Grigoli et al. (2018) discovered that the real deposit rate had a positive effect on household savings. The positive effect of the real interest rate on household savings from both studies indicates that the substitution effect is stronger than the income effect. Conversely, Samantaraya and Patra (2014) found that the real interest rate has a significant negative impact on household savings in Thailand, which suggests that the income effect is stronger than the substitution effect.

Demographic factors have recently become increasingly important for savings in several studies. These demographic factors include such things as family components, ethnicity, education, and region. A reduction in family size contributes to an increase in the household saving rate. Braun et al. (2009), Curtis et al. (2017), and Lugauer et al. (2019) all found a negative relationship between the number of dependent children in the family and the household saving rate. Finlay and Price (2015) provided further empirical evidence that single-parent households tend to save more than other households. 
In the context of ethnicity, Hua and Erreygers (2019) found that ethnicity is a crucial factor in determining the household saving rate in rural areas. Fisher and Hsu (2012) discovered that marital status is associated with a higher likelihood of saving among white households, but not among Hispanic households. On the contrary, their study also discovered that self-employment is correlated with a higher likelihood of saving among Hispanic households, but not among white households.

Various studies have shown that the link between education and household savings may be positive, negative, or neutral. For instance, Horioka and Watanabe (1997) found that, as the level of education increased, the household savings increased. In contrast, Bebczuk et al. (2015) found that education is negatively correlated with household savings. Furthermore, Steinert et al. (2018) concluded that education does not have a significant effect on household savings.

Empirical studies have shown that location or regional factors may influence household saving rates. For example, Guin (2017) analyzed historical language borders in Switzerland and found that households located in the Germanspeaking regions seemed to save more than those located in the French-speaking regions. Examining the different effects of urban-rural areas in China, Lugauer et al. (2019) found that households in urban areas have a higher saving rate than similar households residing in rural areas. However, Hua and Erreygers (2019) documented a different finding-rural households in Vietnam tended to save more than urban households.

Household savings may be affected by financial institutions. Beckmann and Mare (2017) showed that trust in financial institutions by households can enhance savings. Steinert et al. (2018) discovered that savings promotions encouraged household savings, and that its effect is greater than the income effect. Furthermore, there are mixed results regarding the impact of access to financial instruments, particularly access to credit, on household savings. Silva (2012) and Heckman and Hanna (2015) found that access to credit is positively correlated with household savings. In contrast, Jongwanich (2010) and Adema and Pozzi (2015) found that access to credit contributed to a reduction in household savings.

Institutional conditions are considered to affect household savings. Giavazzi and McMahon (2012) provided evidence that household saving increases as policy uncertainty in a country increases. Bebczuk et al. (2015) found that households that receive government transfers, such as subsidies and pensions, reduce their saving rate. Le Blanc et al. (2016) showed that higher income taxes are negatively correlated with household savings. Their study implied that public and personal insurance are substitutes. Furthermore, Hatzinikolaou and Tsoka (2016) and Fulford (2015) provided evidence that social insurance reduced the saving rate.

From these studies, we can conclude that income, uncertainty, inflation, interest rates, demographics, financial situations, and institutions are central to household saving behavior in the literature. A comprehensive analysis of the impact of internet access on household savings, is however, rarely explored in the literature. The link between internet access and household savings is still a new topic. Our study thus adds to the literature by analysing the impact of internet access (both private and public) on household savings. Our micro-level data allows for an indepth understanding of the impact of internet access on household savings at the 
household level. Although there are no clear-cut theoretical studies underlying the effect of internet access on household savings, the effect potentially occurs through the financial inclusion transmission channel. The expansion of internet access is predicted to increase financial inclusion (Andrianaivo and Kpodar, 2012; Bongomin et al., 2018). In turn, an increase in financial inclusion is predicted to increase household savings (Fisher and Hsu, 2012; Deuflhard et al., 2019).

The internet is the main building block of digital finance, such as internet banking and mobile banking. Through this technology, a lot of financial services, including savings accounts, can reach a wider pool of customers and can be delivered at a lower cost. Andrianaivo and Kpodar (2012) and Bongomin et al. (2018) all claim that accessing digital finance via mobile phones contributes to financial inclusion. It has been argued that the high cost of accounts and the long distance from financial institutions (for rural dwellers) are the main barriers to the use of accounts in financial institutions (Beck et al., 2008; Demirguc-Kunt et al., 2015; Allen et al., 2016). In a further study, Demirguc-Kunt et al. (2018) reported that being unbanked meant that these people were also relatively unlikely to have either a mobile phone or access to the internet. Therefore, access to the internet makes it possible for people to access financial services anywhere and anytime, using either a computer or a mobile device. The excluded population should be encouraged to access financial services via digital finance (Ozili, 2018).

Although having an account in a financial institution does not automatically translate into more formal methods of saving, account ownership still matters for household savings behavior. Fisher and Hsu (2012) concluded that being unbanked was associated with a diminished likelihood of saving. This finding implies that having a bank account can encourage people to save more. Nevertheless, a study from Deuflhard et al. (2019) argued that financial literacy has a considerable effect on increasing household savings. Their study suggested that the lack of information may prevent individuals from obtaining the highest possible interest rate from the alternatives. Furthermore, in another study, Becker (2017) and Ky et al. (2018) found that digital finance makes individuals more likely to start first-time savings accounts and increase the amount they save. Given this important theoretical relationship between internet access and household savings, it is surprising that there is no empirical research exploring it. In the next section, we outline our data and method that allow us to empirically tackle this relationship.

\section{DATA AND METHOD}

This study used micro-level data to analyze household savings. The Indonesian Family Life Survey (IFLS) was used as the primary dataset because it contained detailed information about asset diversification and internet access. The IFLS allowed this study to derive the total amount of savings and other assets. With this information, we can estimate households' preferences for savings assets. In addition, the dataset provides detailed information about the availability of financial services and whom the household's decision-maker is-which other large micro-datasets do not have. Although the IFLS is a panel dataset, this study only used the fifth wave of the IFLS (i.e. IFLS5). We only use IFLS5 because internet-related questions were first asked in this edition. Thus, we cannot exploit this dynamic from the previous waves of the IFLS. 
The IFLS5 data collection was conducted in 2014 and covered over 30,000 individuals and around 15,000 households. The survey was conducted in 13 Indonesian provinces. The data contains-but not limited to-internet access details, asset details, households' socioeconomic characteristics, community details, financial services' availability, and households' decision-making processes (Strauss et al., 2016).

This study analyzes the impact of internet access on households' savings using the OLS estimator to estimate the regression models shown in Equations (1) and (2). $h$ and $p$ subscripts, respectively, denote the household and the province. $S A V I N G_{h p}$ denotes savings in household $h$ in province $p$. We measured household savings using two proxies. The first is the natural logarithm of the amount of savings and captures the change in the amount of savings. The second is the share of the amount of savings compared to the total asset value, which captures the behavioral change of households in diversifying their assets.

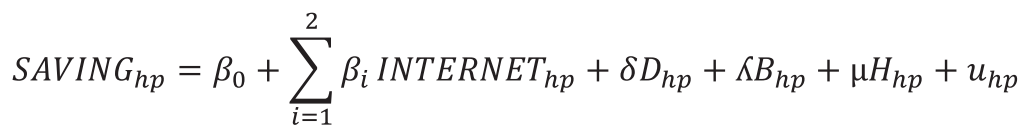

INTERNET $T_{h p}$ which is a categorical variable, denotes the internet access of household $h$ in province $p$. Internet access is analyzed into two parts. The first part only focuses on the households' heads internet access. This part categorizes internet access into three categories, namely (1) the household's head has no internet access (as a base category), (2) the household's head has private internet access $\left(\beta_{1}\right)$, and (3) the household's head has only public internet access $\left(\beta_{2}\right)$. Private internet access is defined as access to the internet using a handphone, a desktop computer, or a laptop. Public internet access is defined as access to the internet using a computer in school, at the workplace, or at an internet cafe.

$$
S A V I N G_{h p}=\alpha_{0}+\sum_{i=1}^{3} \alpha_{i} I N T E R N E T_{h p}+\theta D_{h p}+\psi B_{h p}+\gamma H_{h p}+\varepsilon_{h p}
$$

The second part elaborates whom has private internet access in the household. We categorize this variable into four categories, namely (1) no one in the household has private internet access (as a base category), (2) only the household's head has private internet access $\left(\alpha_{1}\right)$, (3) the household's head does not have private internet access, but a minimum of one household member has private internet access $\left(\alpha_{2}\right)$, and (4) the household's head and other members have private internet access $\left(\alpha_{3}\right)$. 
Table 1.

Summary Statistics

This table reports the descriptive statistics for the dependent variables (log savings and share of savings) and independent variables. The statistics include the number of observations, mean, standard deviation (Std. Dev.), minimum (Min) and maximum (Max) values. The data is obtained from IFLS5.

\begin{tabular}{lccccc}
\hline Variable & Obs & Mean & $\begin{array}{c}\text { Std. } \\
\text { Dev. }\end{array}$ & Min & Max \\
\hline Log savings & 6,146 & 4.047 & 6.670 & 0 & 20.071 \\
Share of savings & 6,146 & 0.018 & 0.067 & 0 & 0.889
\end{tabular}

\section{Internet Access}

- 1 if head of household does not have access to the internet, 0 otherwise

- 1 if head of household only has public internet, 0 otherwise

- 1 if head of household only has private internet, 0 otherwise

\section{Has Private Internet Access}

- 1 if no-one in the household has private internet access, 0 otherwise

- 1 if only head of household has private internet access, 0 otherwise

- 1 if households' member other than head of household has private internet access, 0 otherwise

- 1 if head of household and households' member have private internet access, 0 otherwise

\section{Household decision making process}

- 1 if saving decision determined by head of household only, 0 otherwise

- 1 if saving decision determined by the head of households' spouse only, 0 otherwise

- 1 if saving decision determined by the head of household and their spouse, 0 otherwise

- 1 if saving decision determined by other members, 0 otherwise

Log total assets

Log total yearly earnings

Log head of households' yearly earnings

Log spouse head of households' yearly earnings

Head of households' years of education

Spouse of head of households' years of education

1 if head of households' sex, 0 otherwise

Head of households' age

1 if spouse of head of households' sex, 0

otherwise

Household size

Number of working household member

Distance to the nearest Bank Rakyat Indonesia (BRI)

$\begin{array}{lllll}6,146 & 0.816 & 0.387 & 0 & 1 \\ 6,146 & 0.022 & 0.146 & 0 & 1 \\ 6,146 & 0.162 & 0.387 & 0 & 1\end{array}$

$\begin{array}{lllll}6,146 & 0.523 & 0.500 & 0 & 1\end{array}$

$\begin{array}{lllll}6,146 & 0.064 & 0.245 & 0 & 1\end{array}$

$\begin{array}{lllll}6,146 & 0.315 & 0.464 & 0 & 1\end{array}$

$\begin{array}{lllll}6,146 & 0.098 & 0.297 & 0 & 1\end{array}$

$\begin{array}{lllll}6,146 & 0.005 & 0.071 & 0 & 1\end{array}$

$\begin{array}{lllll}6,146 & 0.357 & 0.479 & 0 & 1\end{array}$

$\begin{array}{lllll}6,146 & 0.257 & 0.437 & 0 & 1\end{array}$

$\begin{array}{lllll}6,146 & 0.381 & 0.486 & 0 & 1\end{array}$

$\begin{array}{lllll}6,146 & 18.046 & 1.492 & 10.820 & 21.474\end{array}$

$\begin{array}{lllll}6,146 & 14.808 & 5.332 & 0 & 20.425\end{array}$

$\begin{array}{lllll}6,146 & 12.864 & 6.717 & 0 & 20.723\end{array}$

$\begin{array}{lllll}6,146 & 6.467 & 7.751 & 0 & 20.723\end{array}$

$\begin{array}{lllll}6,146 & 7.745 & 4.478 & 0 & 19\end{array}$

$\begin{array}{lllll}6,146 & 7.437 & 4.416 & 0 & 18\end{array}$

$\begin{array}{lllll}6,146 & 0.985 & 0.122 & 0 & 1\end{array}$

$\begin{array}{lllll}6,146 & 46.618 & 13.489 & 18 & 92\end{array}$

$\begin{array}{lllll}6,146 & 41.983 & 12.765 & 15 & 92\end{array}$

$\begin{array}{lllll}6,146 & 4.150 & 1.595 & 1 & 15\end{array}$

$\begin{array}{lllll}6,146 & 2.049 & 1.006 & 0 & 8\end{array}$

$\begin{array}{lllll}6,146 & 53.260 & 84.182 & 0.01 & 200\end{array}$


Table 1.

Summary Statistics (Continued)

\begin{tabular}{|c|c|c|c|c|c|}
\hline Variable & Obs & Mean & $\begin{array}{l}\text { Std. } \\
\text { Dev. }\end{array}$ & Min & $\operatorname{Max}$ \\
\hline $\begin{array}{l}\text { Distance to the nearest Bank Perkreditan Rakyat } \\
\text { (BPR) }\end{array}$ & 6,146 & 92.311 & 95.701 & 0.2 & 200 \\
\hline $\begin{array}{l}\text { Distance to the nearest Village Credit Institution } \\
\text { (LKD) }\end{array}$ & 6,146 & 187.177 & 47.803 & 0.01 & 200 \\
\hline $\begin{array}{l}\text { Distance to the nearest Village Cooperative unit } \\
\text { (KUD) }\end{array}$ & 6,146 & 142.402 & 89.213 & 0.2 & 200 \\
\hline Distance to the nearest bank & 6,146 & 151.738 & 83.517 & 0.1 & 200 \\
\hline Distance to the nearest cooperatives & 6,146 & 74.728 & 90.680 & 0.1 & 200 \\
\hline $\begin{array}{l}\text { Distance to the nearest Baitul Maal wat Tamwil } \\
\text { (BMT) }\end{array}$ & 6,146 & 157.158 & 79.705 & 0.5 & 200 \\
\hline Distance to the nearest sharia bank & 6,146 & 84.343 & 91.626 & 0.05 & 200 \\
\hline BRIs' number of services & 6,146 & 5.057 & 2.502 & 1 & 10 \\
\hline Banks' number of services & 6,146 & 4.456 & 3.316 & 0 & 10 \\
\hline Sharia banks' number of services & 6,146 & 3.156 & 3.197 & 0 & 10 \\
\hline 1 if household lives in urban area, 0 otherwise & 6,146 & 0.524 & 0.499 & 0 & 1 \\
\hline
\end{tabular}

Table 1 shows that approximately $52.37 \%$ of households live in the urban area. Total savings asset defines the monetary value of assets held by the households. Based on 6,146 households, the average value of assets from the savings held by each household is roughly 4.8 million Indonesian rupiahs and it ranges up to one billion Indonesian rupiahs. The share of savings is the portion of the monetary value of assets in total assets held as savings. The average share of savings is $2 \%$ of the household total assets with a standard deviation of $7 \%$ and a maximum value of $89 \%$. Of the households surveyed, 3,216 households do not have any one member with private internet access. For the $9.79 \%$ of the households, whose head and members have private internet access, only $20 \%$ of them are rural households (the remaining $80 \%$ are urban households). Considering households whose members have control in the saving decision-making processes, we observed that only $0.5 \%$ households reported that their savings are decided solely by the head of the family. For $35.67 \%$ of the households, the spouse of the head makes saving decisions, whereas $25.67 \%$ of the households jointly make their saving decisions. The remaining $38.16 \%$ households have other members in the family making the saving decision.

Using a simple OLS estimator to estimate the correlation between internet access and household savings would have yielded biased results (we will discuss this later in Section IV). We conducted a $t$-test to find the difference between the household heads with internet access and those without internet access. We found the difference in the share of savings was $2.6 \%$ higher for household heads with internet access. This result is unbiased if access to the internet is random. However, our $t$-test results in Table 2 shows that access to the internet is not random. Most of the variables we tested gave us significant results with a $99 \%$ level of confidence. A person, whom has access to the internet, is wealthier, more deliberate in his/ her decision-making processes, better educated, younger, has fewer household members, and lives in an urban area. 
Table 2.

Balanced Test based on Internet Ownership by Head of Household

Columns (1) and (2) of this table report mean characteristics of head of household. Column (3) of this table reports values of $t$-test. * **,*** denote, respectively, significance at $10 \%, 5 \%$, and $1 \%$ level. Standard errors are in the parentheses.

\begin{tabular}{|c|c|c|c|}
\hline Variable & $\begin{array}{l}\text { Have } \\
\text { internet } \\
\text { access } \\
\text { (1) }\end{array}$ & $\begin{array}{l}\text { Do not } \\
\text { have } \\
\text { internet } \\
\text { access } \\
(2)\end{array}$ & $\begin{array}{l}\text { diff } t \text {-test } \\
\quad \text { (3) }\end{array}$ \\
\hline Log savings & $\begin{array}{c}7.262 \\
(0.231)\end{array}$ & $\begin{array}{c}3.322 \\
(0.087)\end{array}$ & $\begin{array}{l}3.940^{* * *} \\
(0.213)\end{array}$ \\
\hline Share of savings & $\begin{array}{c}0.039 \\
(0.003)\end{array}$ & $\begin{array}{c}0.013 \\
(0.001)\end{array}$ & $\begin{array}{l}0.025^{* * *} \\
(0.002)\end{array}$ \\
\hline \multicolumn{4}{|l|}{ Household decision making process } \\
\hline $\begin{array}{l}\text { - } 1 \text { if saving's decision determined by head of } \\
\text { household only, } 0 \text { otherwise }\end{array}$ & $\begin{array}{r}0.006 \\
(0.002)\end{array}$ & $\begin{array}{l}0.005 \\
(0.001)\end{array}$ & $\begin{array}{l}0.001 \\
(0.002)\end{array}$ \\
\hline $\begin{array}{l}\text { - } 1 \text { if saving's decision determined by the head of } \\
\text { households' spouse only, } 0 \text { otherwise }\end{array}$ & 0.433 & 0.340 & $0.093^{* * *}$ \\
\hline & $(0.015)$ & $(0.007)$ & $(0.016)$ \\
\hline $\begin{array}{l}\text { - } 1 \text { if saving's decision determined by the head of } \\
\text { household and their spouse, } 0 \text { otherwise }\end{array}$ & 0.367 & 0.232 & $0.135^{* * *}$ \\
\hline & $(0.014)$ & $(0.006)$ & $(0.014)$ \\
\hline $\begin{array}{l}\text { - } 1 \text { if saving's decision determined by other members, } \\
0 \text { otherwise }\end{array}$ & 0.194 & 0.424 & $-0.230^{* * *}$ \\
\hline & $(0.012)$ & $(0.007)$ & $(0.016)$ \\
\hline Log total assets & $\begin{array}{l}18.347 \\
(0.047)\end{array}$ & $\begin{array}{l}17.978 \\
(0.021)\end{array}$ & $\begin{array}{l}0.370^{* * *} \\
(0.048)\end{array}$ \\
\hline Log total yearly earnings & $\begin{array}{l}16.252 \\
(0.122)\end{array}$ & $\begin{array}{l}14.482 \\
(0.078)\end{array}$ & $\begin{array}{c}1.771^{* * *} \\
(0.174)\end{array}$ \\
\hline Log head of households' yearly earnings & $\begin{array}{l}15.102 \\
(0.158)\end{array}$ & $\begin{array}{l}12.359 \\
(0.097)\end{array}$ & $\begin{array}{c}2.742^{* * *} \\
(0.218)\end{array}$ \\
\hline Log spouse head of households' yearly earnings & $\begin{array}{c}8.314 \\
(0.243)\end{array}$ & $\begin{array}{c}6.051 \\
(0.107)\end{array}$ & $\begin{array}{l}2.262^{* * *} \\
(0.253)\end{array}$ \\
\hline Head of households' years of education & $\begin{array}{l}12.007 \\
(0.096)\end{array}$ & $\begin{array}{c}6.785 \\
(0.058)\end{array}$ & $\begin{array}{l}5.222^{* * *} \\
(0.132)\end{array}$ \\
\hline Spouse of head of households' years of education & $\begin{array}{l}11.389 \\
(0.102)\end{array}$ & $\begin{array}{c}6.547 \\
(0.058)\end{array}$ & $\begin{array}{l}4.841^{* * *} \\
(0.131)\end{array}$ \\
\hline 1 if head of households' sex, 0 otherwise & $\begin{array}{c}0.995 \\
(0.002)\end{array}$ & $\begin{array}{c}0.983 \\
(0.002)\end{array}$ & $\begin{array}{l}0.012^{* * *} \\
(0.004)\end{array}$ \\
\hline Head of households' age & $\begin{array}{l}36.903 \\
(0.269)\end{array}$ & $\begin{array}{l}48.806 \\
(0.189)\end{array}$ & $\begin{array}{c}-11.903^{* * *} \\
(0.417)\end{array}$ \\
\hline 1 if spouse of head of households' sex, 0 otherwise & $\begin{array}{l}33.476 \\
(0.267)\end{array}$ & $\begin{array}{l}43.983 \\
(0.179)\end{array}$ & $\begin{array}{c}-10.423^{* * *} \\
(0.399)\end{array}$ \\
\hline Household size & $\begin{array}{c}4.032 \\
(0.041)\end{array}$ & $\begin{array}{c}4.176 \\
(0.023)\end{array}$ & $\begin{array}{c}-0.143^{* * *} \\
(0.052)\end{array}$ \\
\hline Number of working household member & $\begin{array}{c}1.865 \\
(0.024)\end{array}$ & $\begin{array}{c}2.091 \\
(0.015)\end{array}$ & $\begin{array}{c}-0.225^{* * *} \\
(0.033)\end{array}$ \\
\hline
\end{tabular}


Table 2.

Balanced Test based on Internet Ownership by Head of Household (Continued)

\begin{tabular}{lccc}
\hline \multicolumn{1}{c}{ Variable } & $\begin{array}{c}\text { Have } \\
\text { internet } \\
\text { access } \\
\mathbf{( 1 )}\end{array}$ & $\begin{array}{c}\text { Do not } \\
\text { have } \\
\text { internet } \\
\text { access } \\
\mathbf{( 2 )}\end{array}$ & $\begin{array}{c}\text { diff } \boldsymbol{t} \text {-test } \\
(3)\end{array}$ \\
\hline Distance to the nearest Bank Rakyat Indonesia (BRI) & 68.899 & 49.738 & $19.161^{* * *}$ \\
Distance to the nearest Bank Perkreditan Rakyat (BPR) & $(2.748)$ & $(1.155)$ & $(2.761)$ \\
& 94.759 & 91.760 & 2.999 \\
Distance to the nearest Village Credit Institution (LKD) & $(2.877)$ & $(1.348)$ & $(3.151)$ \\
& 188.696 & 186.834 & 1.862 \\
Distance to the nearest Village Cooperative unit (KUD) & $(1.354)$ & $(0.682)$ & $(1.574)$ \\
& 149.151 & 140.882 & $8.269^{* * *}$ \\
Distance to the nearest bank & $(2.558)$ & $(1.269)$ & $(2.936)$ \\
Distance to the nearest cooperatives & 85.061 & 72.400 & $12.661^{* * *}$ \\
& $(2.818)$ & $(1.157)$ & $(2.981)$ \\
Distance to the nearest Baitul Maal wat Tamwil (BMT) & 160.401 & 149.787 & $10.611^{* * *}$ \\
Distance to the nearest sharia bank & $(2.328)$ & $(1.194)$ & $(2.747)$ \\
& 167.046 & 154.931 & $12.115^{* * *}$ \\
BRIs' number of services & $(2.149)$ & $(1.146)$ & $(2.620)$ \\
& 87.976 & 83.525 & 4.451 \\
Banks' number of services & $(2.796)$ & $(1.286)$ & $(3.017)$ \\
Sharia banks' number of services & 5.039 & 5.062 & -0.023 \\
1 if household lives in urban area, 0 otherwise & $(0.076)$ & $(0.035)$ & $(0.082)$ \\
\hline Observation & 4.562 & 4.432 & 0.131 \\
& $(0.100)$ & $(0.047)$ & $(0.109)$ \\
& 3.265 & 3.132 & 0.133 \\
& $(0.094)$ & $(0.045)$ & $(0.105)$ \\
& 0.706 & 0.483 & $0.224^{* * *}$ \\
& $(0.014)$ & $(0.007)$ & $(0.016)$ \\
\hline
\end{tabular}

To reduce bias of the simple OLS estimates, we added control variables that are potentially strongly correlated to internet access and saving decisions. First, we estimated the correlation between internet access and savings by adding the decision-maker control for household savings $\left(D_{h p}\right)$. By adding this covariate, we corrected the upward bias of the estimates derived from the simple OLS. However, adding this covariate does not eliminate the bias. Our argument is that when households do not have access to banks, they are less diversified with their assets in the form of savings accounts. Another potential threat to our results is variations in the household characteristics. For example, a more prosperous household tends to have more access to the internet and a higher amount of savings.

We thus control for additional factors including access to banks $\left(B_{h p}\right)$ and household characteristics $\left(H_{h p}\right)$ to reduce the bias. We decomposed household characteristics by total assets value, households' yearly earnings, household heads and their spouses' earnings, household heads and their spouses' education and 
work attainment, household composition, and living area characteristics. Details of the variables used in this study are in Table A1 in the appendix. We showed that adding these variables led to a more valid estimation (we discuss this point later in Section IV).

Furthermore, we controlled for province fixed effect to minimize the bias that comes from unobserved heterogeneity at the provincial level. The reason we apply the province fixed effect is because Indonesia has unique characteristics, including different levels of and cultural variations across provinces. These characteristic variations imply there are heterogeneity effects for individuals living in different provinces. For example, individuals living in a province with a high standard of internet infrastructure have a higher chance of using the internet and banking services, compared to individuals who live in less developed provinces. We also clustered the standard errors at the district level to correct miscalculated standard errors caused by individual correlations within a district (Cameron and Miller, 2015).

Table 3.

Sample Restriction

This table shows the sample restriction criteria. - denotes not applicable.

\begin{tabular}{lcc}
\hline Sample Restriction Criteria & $\begin{array}{c}\text { Number } \\
\text { of samples } \\
\text { dropped }\end{array}$ & $\begin{array}{c}\text { Total } \\
\text { sample }\end{array}$ \\
\hline Initial Sample & - & 15,094 \\
$\quad$ Drop if household's characteristics information is missing & 1,270 & 13,824 \\
Drop if saving's decision-maker's information is missing & 3,463 & 10,361 \\
Drop if living area information is missing & 107 & 10,254 \\
Drop if financial access information is missing & 3,950 & 6,304 \\
$\quad$ Drop if asset information is missing & 158 & 6,146 \\
\hline Total Sample used & - & 6,146 \\
\hline
\end{tabular}

The estimation is based on a sample of 6,146 households from a total sample of 15,094 households in the IFLS5. In other words, this study only used $40.72 \%$ of the total sample. We created a sample restriction criterion to obtain the final sample. First, samples that did not have complete information regarding household characteristics were dropped. Then, households for which information was missing about the decision-making processes, living area conditions, and financial access were also excluded from our final sample. Finally, we dropped the households with missing information about asset diversification. We summarized our sample's restriction criterion in Table 3.

\section{RESULTS AND DISCUSSION}

The simple OLS estimates in Table 4, Column A1, show that household heads with private or public internet access, in general, have more than three times the savings of those without internet access - although after adding the control variables to the regression, as indicated by Columns A2 until A4, the coefficient decreased. 
This finding strengthens our argument in Section III that a simple OLS regression leads to biased estimates. With all the control variables added to the regression, we found that household heads with private internet access have $129.4 \%$ more in savings compared to those without internet access. Household heads with public internet access have $139.3 \%$ more in savings compared to those who do not have access. This finding implies that there is a strong correlation between internet access and an increase in household savings. With or without the control variables, the estimates consistently show a significant correlation between internet access and household savings.

Our results in Table 4 show that access to the internet, both private and public, has a strong positive correlation with the amount saved. There is a potential argument regarding why this finding may be doubtful. For example, someone who is wealthier has a higher probability of having internet access and, therefore, higher savings. Moreover, our estimation shows that the correlation is strictly significant after controlling for household yearly earnings. We can say that, if all the other factors are equal for households, differences in their methods of accessing the internet can lead to a higher amount being saved.

We found similar results when we ran the estimation using a different proxy for household savings. The share of savings was used in the regression estimates shown by Columns B1 until B4 in Table 4. The coefficients using the simple OLS estimator are significant and similar to estimates using the logarithm of savings as a proxy for household savings, in that the coefficients are continually decreasing. Nevertheless, we find different results, in terms of the significance of the coefficient. We found no significant difference between the household heads with public internet access and the household heads without internet access, in terms of their share of savings; although there is a significant difference between the household heads with private internet access and those without internet access. The households with private internet access have a share of savings that is $1 \%$ higher than those without internet access. Our findings suggest that public internet access only increases the amount of savings, but not the share of savings, whereas private internet access increases both the amount and share of savings.

Next, we elaborate on the effect of individuals' private internet access on household on saving. We regressed households' private internet access on household savings. These estimates, which are recorded in Table 5, show that private internet access will increase the amount of savings, if and only if the head of the household has private internet access. For households whose private internet is only accessed by the heads of the households, the amount of savings increased by $68.3 \%$, although this has only a $10 \%$ level of significance. If private internet access is jointly accessed by the head of the household and other members of the household, the effect is higher. We found that when the head of the household and other members jointly accessed the internet by private means, the amount saved was $152.3 \%$ higher compared to households which did not have private internet access. The effect is significant with a $99 \%$ level of confidence. In addition, if the private internet is only accessed by other members of the household, the effect is no longer as significant. 


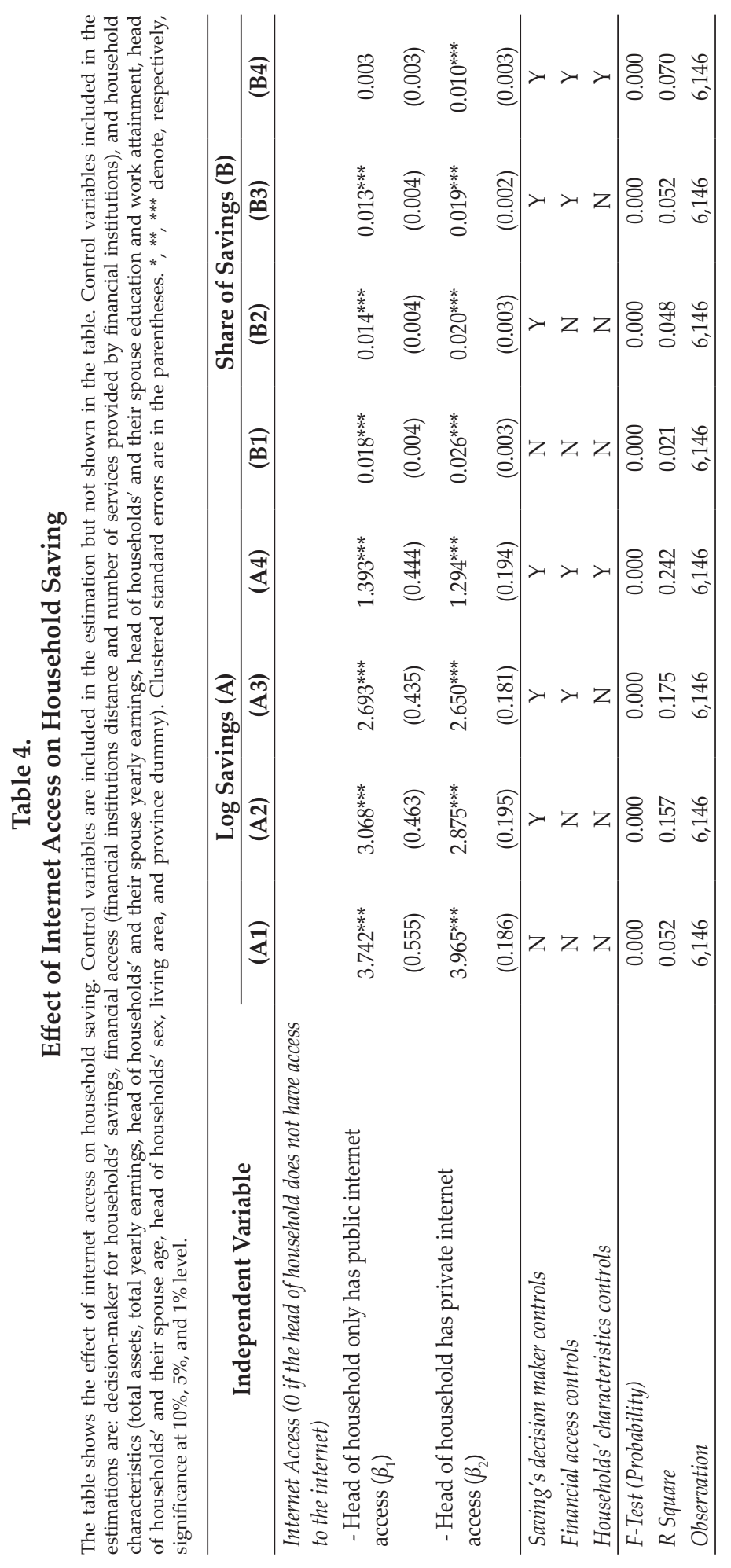




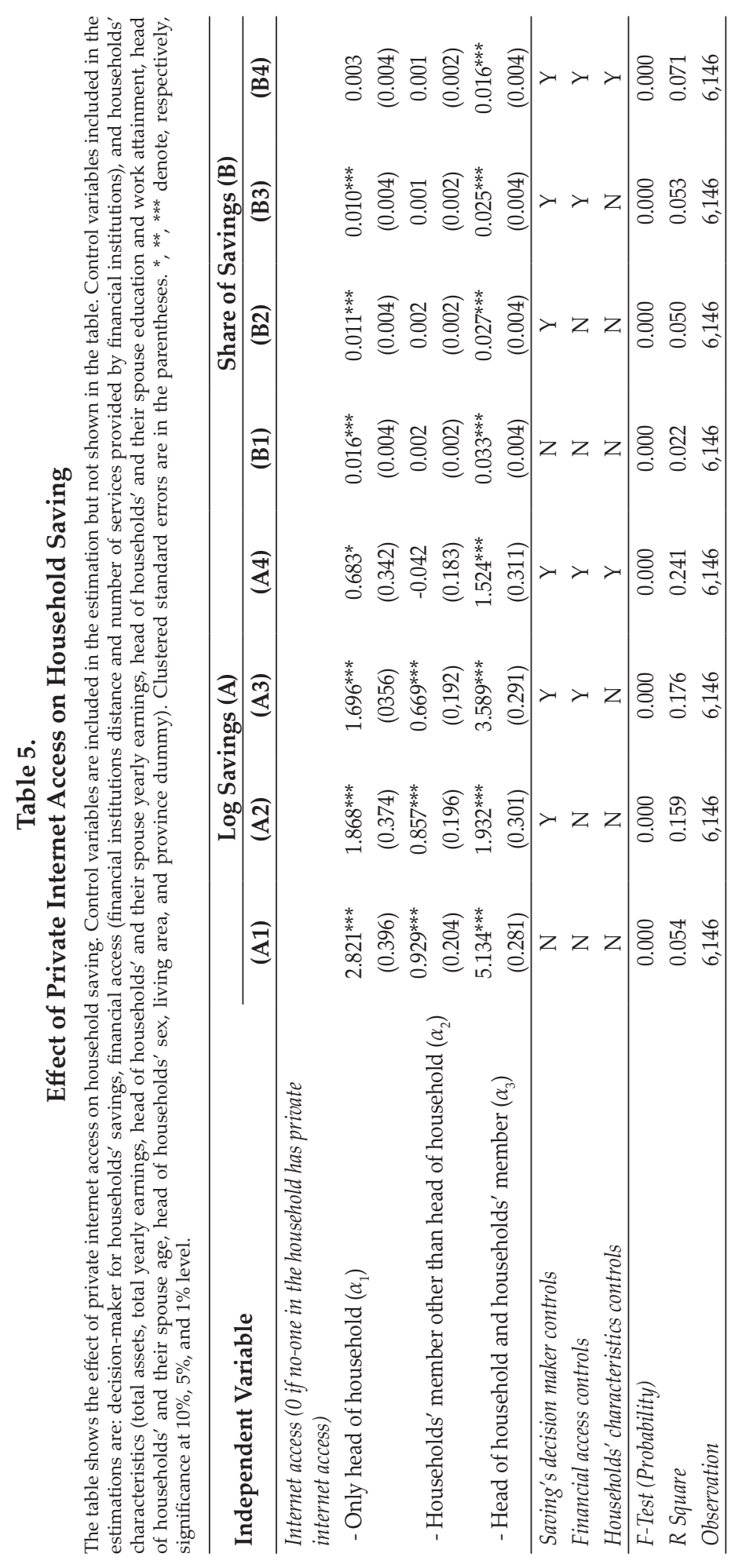


Contrasting results were obtained when we ran the regressions using the share of savings as a dependent variable. Private internet access is significant only if the internet is accessed by the head of the household and other members jointly. If only the head of the household or other members have private internet access, the impact is not significant. This finding suggests that private internet access is important for increasing the household's preference to save if the access is held by the head of the household and other members. This is explained by the phenomenon that household members have less influence over household decision-making processes compared to the head of the household.

We also explored the heterogeneous effect of infrastructure. To do this, we grouped regressions based on the location of households (i.e. urban vs. rural households) and report the results in Table 6. For urban households, the estimated effect of internet access on savings is consistent with the previous findings. However, for rural households, the share of savings is decreased when the head of the household accesses the internet through public means. This result can be explained by the interactions within a community in rural areas. Through public access, the head of the household can interact with others when accessing the internet. This interaction can give the head of the household additional information, which is shared by his/her neighbours about alternative investments. This information leads to an increase in investments in other assets, rather than an increase in the amount of savings. The information-interaction effect also explains why there is no significant effect on the amount of savings (see Table 6, Column 2).

By using other indicators for internet access (as shown in Table 7), we found that households in which only the heads have access to the internet were no different from those without private internet access, except for those in rural areas. Access to private internet by the household heads only increased the amount of savings, while the share of savings remained steady. This phenomenon is explained by two possibilities: (1) Households in urban areas have a lot of information that is obtained from many sources, so having internet access alone is not enough to increase the willingness to save; (2) the household heads in urban areas are well informed about alternative kinds of investments, so internet access not only increases the amount of savings but also increases the value of other investment assets.

Our estimates in Table 7 show that private internet accessed jointly by the head of the household and other members simultaneously increased the amount of the share of savings both in urban and rural areas. The effect of internet access is more pronounced in urban areas. The coefficient for rural households is twice as significant as compared to that of urban households. Moreover, an increase in internet access in the rural areas, which have poor communication infrastructure, leads to a significant increase in household savings in these areas.

We also explored the potential mechanism explaining how internet access affected household saving behavior. We did this by performing a regression based on literacy skills. We argued that a person with reading ability should obtain more benefits from having internet access, since the internet provides a lot of information about asset portfolio instruments, whereas a person with no ability does not benefit from being exposed to the internet. Tables 8 and 9 summarize our results. By comparing the coefficient for a group of individuals who can read with 


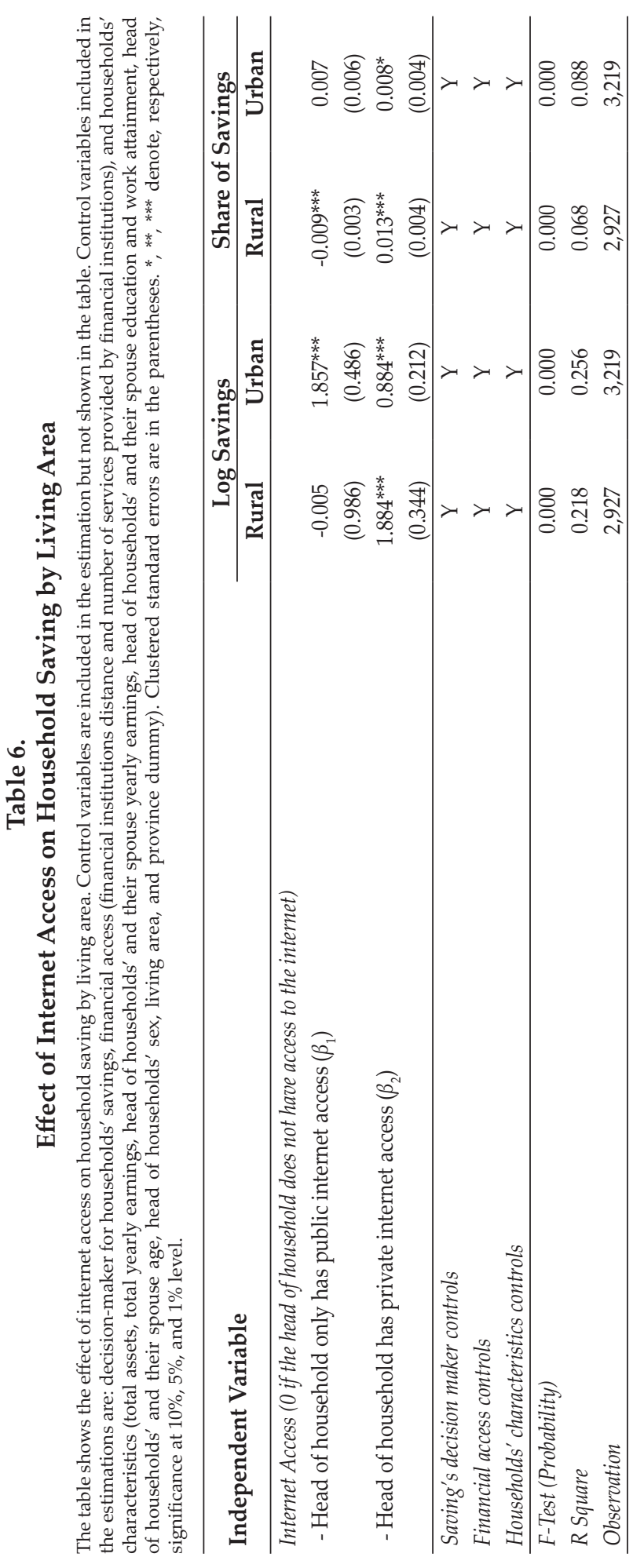




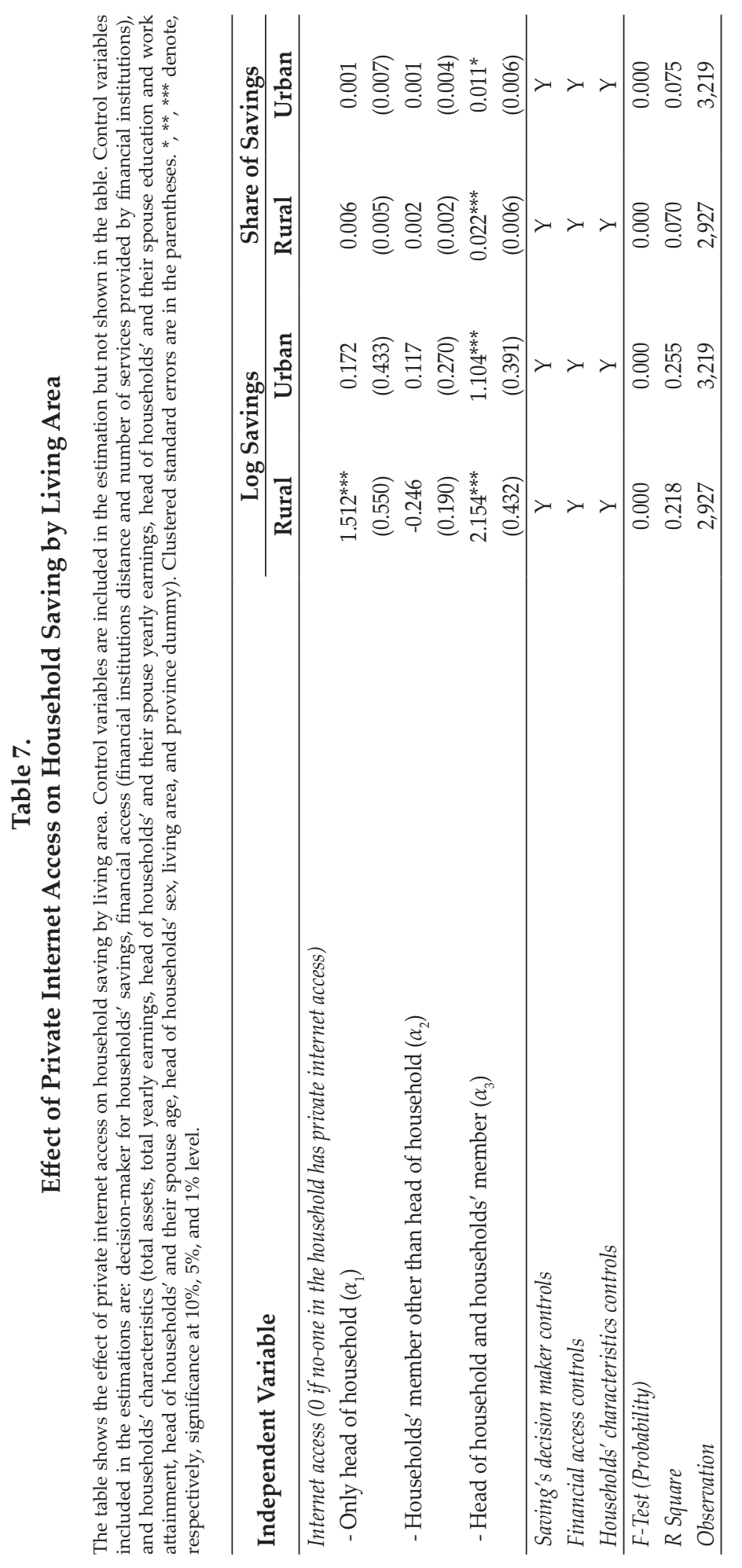


the coefficient for others who cannot read, we conclude that they are significantly different. Internet access has a positive impact on household savings only for the individuals who can read, while, for the individuals who cannot read, the impact is negative.

The contradiction of the internet's effect on the saving behavior between these two groups is not surprising. In our model, we have controlled for the household's level of income. As additional information, the type of asset in the IFLS5 is mostly dominated by physical assets like land, buildings, crops, jewellery, and other types of conventional assets. With the same level of income, individuals who can read are able to get information from the internet about how to save their money, since bank procedures need greater levels of literacy than other assets reported in the IFLS5. In contrast, for individuals who cannot read, having internet access means that they know other types of investments do not require the ability to read. This reason causes this group to put their money in those types of assets, but not savings accounts. Therefore, the internet positively increases household savings through the information given on it. The information affects the household's decision to place their money into different types of assets.

\section{CONCLUSION AND POLICY RECOMMENDATION}

The study examines whether internet access influences household savings in Indonesia, in terms of the amount of savings and the saving preferences. Generally, the study found that internet access (private and public) has a positive impact on household savings. The study showed that public internet access only increases the amount of savings, but not the saving preferences, whereas private internet access positively impacts both the amount of savings and the saving preferences. The study also found that when the private internet is accessible to all household members, household savings is greater than when the private internet is accessible to either household heads or other members only. These findings suggest that internet access does not only influence financial inclusion, as documented by previous studies, but it also influences the household savings.

Our findings can be adopted by policymakers to increase the amount of national savings as well as third-party funds in banks. If Indonesian policymakers only want to increase the total amount of savings, increased access to the internet is essential. Areas with low internet access and usage must be prioritise by policymakers. The expansion of internet access can be achieved by increasing mobile phone, personal computer, and laptop usage in the country. Our findings suggest that an expansion of internet access in the rural areas will have a larger impact on savings than an equivalent expansion in the urban areas. Moreover, if policymakers also want to increase society's willingness to save, internet utilization strategies for all the age-groups should be developed. Private internet access can increase the saving preferences if the internet is not only accessed by the heads of the households, but by other members as well.

It is important to note that, while increasing household savings through expanding internet access is necessary, it is not, by itself, sufficient. If policymakers want to ensure that the expanded internet access increases the amount saved as well as saving preferences, the literacy rate of the population should be improved. 


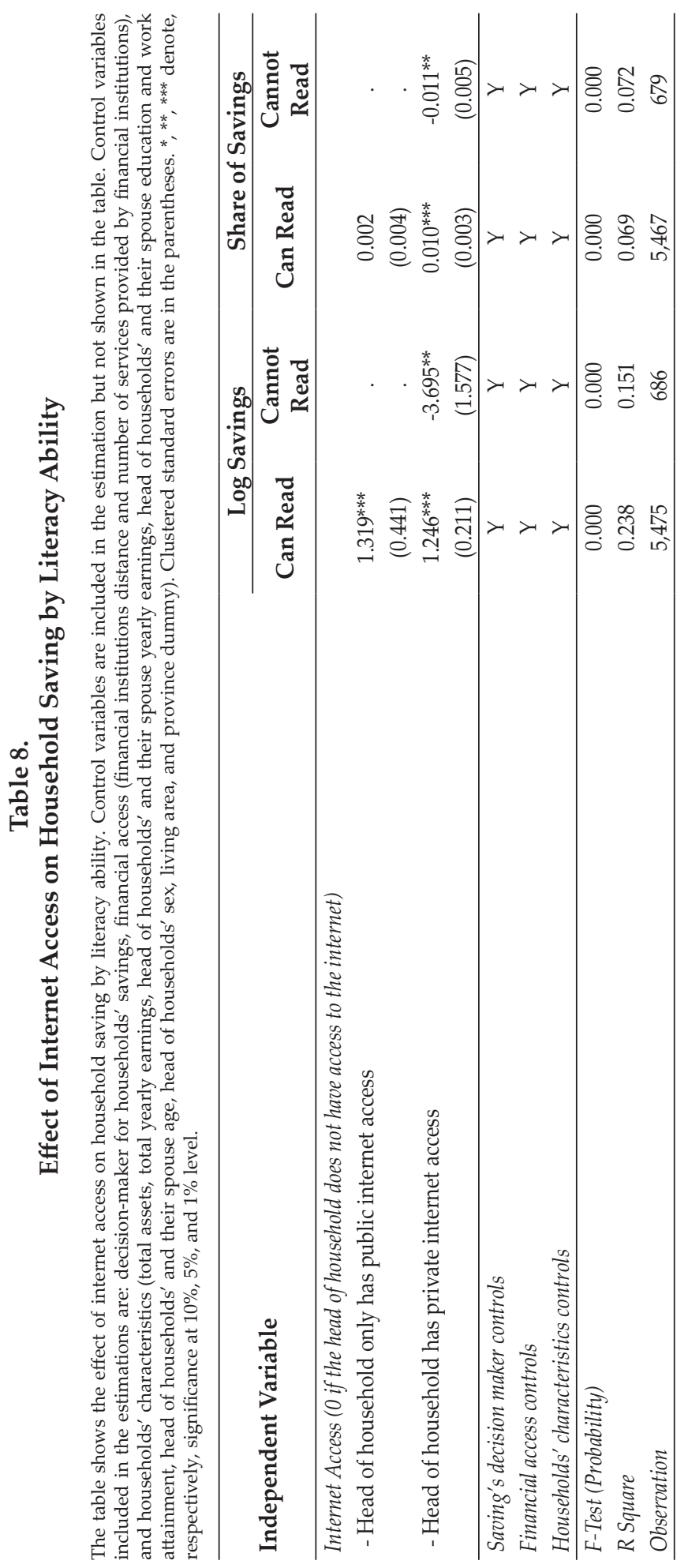




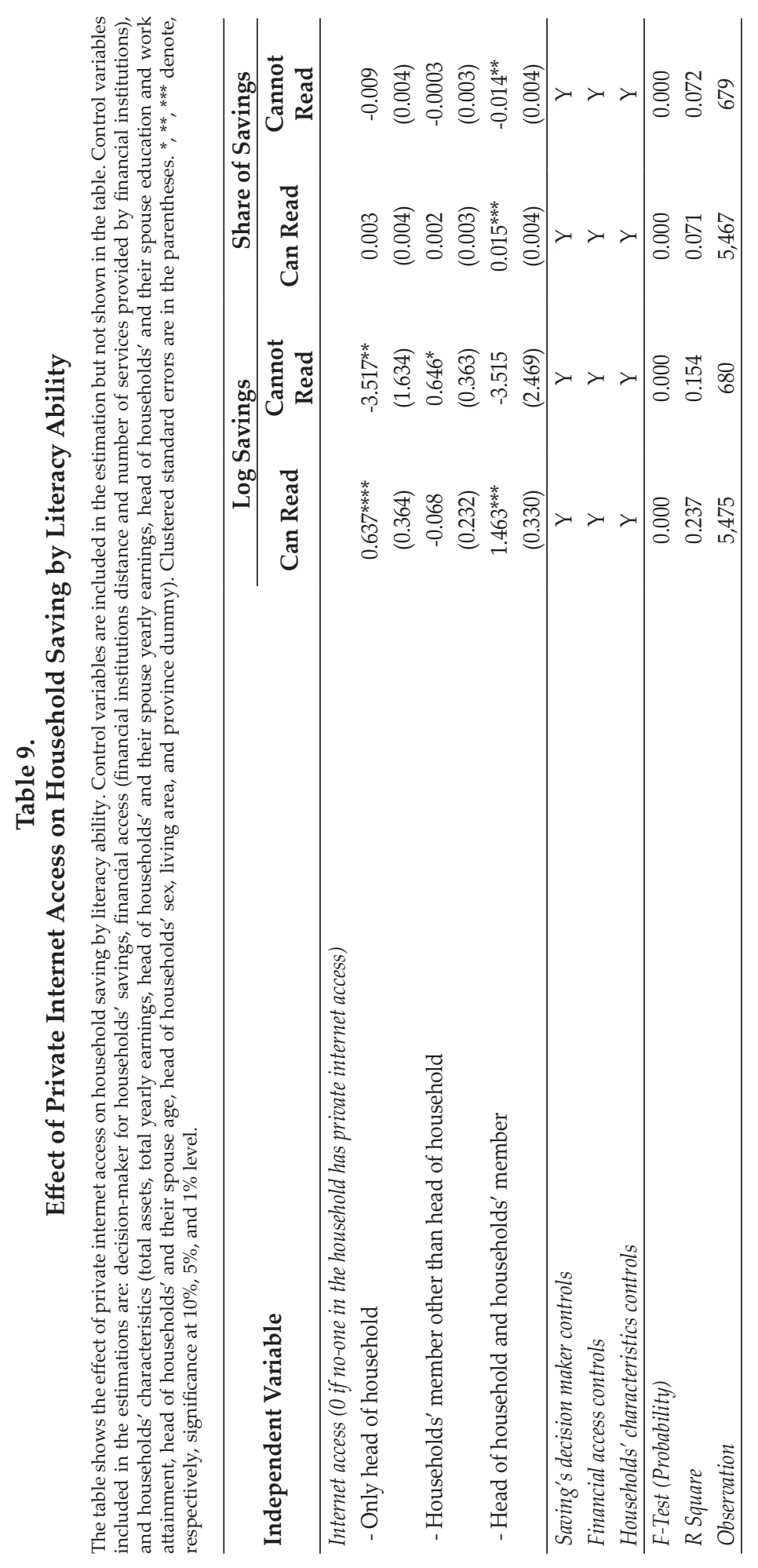


According to Statistics Indonesia, there are still $4.10 \%$ of Indonesians over 15 years of age, who cannot read. ${ }^{2}$ Unless this is dealt with, the expansion of the internet will have a negative impact on savings, instead of increasing the amount of savings and the saving preferences.

\section{REFERENCES}

Adema, Y., \& Pozzi, L. (2015). Business Cycle Fluctuations and Household Saving in OECD Countries: A Panel Data Analysis. European Economic Review, 79, 214233.

Allen, F., Demirgüç-Kunt, A., Klapper, L., \& Peria, M. S. M. (2016). The Foundations of Financial Inclusion: Understanding Ownership and Use of Formal Accounts. Journal of Financial Intermediation, 27, 1-30.

Andrianaivo, M., \& Kpodar, K. (2012). Mobile Phones, Financial Inclusion, and Growth. Review of Economics and Institutions, 3, 30.

Athukorala, P. C., \& Tsai, P. L. (2003). Determinants of Household Saving in Taiwan: Growth, Demography and Public Policy. The Journal of Development Studies, 39, 65-88.

Banu, I. M. (2013). The Impact of Credit on Economic Growth in the Global Crisis Context. Procedia Economics and Finance, 6, 25-30.

Bebczuk, R. N., Gasparini, L., Garbero, M. N., \& Amendolaggine, J. (2015). Understanding the Determinants of Household Saving: Micro Evidence for Latin America. Documentos de Trabajo del CEDLAS.

Beck, T., Demirgüç-Kunt, A. \& Peria, M. S. M. (2008). Banking Services for Everyone? Barriers to Bank Access and Use around the World. World Bank Economic Review, 22, 397-430.

Beck, T., Pamuk, H., Ramrattan, R., \& Uras, B. (2015). Mobile Money, Trade Credit, and Economic Development: Theory and Evidence. Discussion Paper, 2015-023.

Becker, G. (2017). Does Fintech Affect Household Saving Behavior? Findings from a Natural Field Experiment. Working Paper.

Beckmann, E., \& Mare, D. S. (2017). Formal and Informal Household Savings: How Does Trust in Financial Institutions Influence the Choice of Saving Instruments? Available at SSRN 3023711.

Bongomin, G. O. C., Ntayi, J. M., Munene, J. C., \& Malinga, C. A. (2018). Mobile Money and Financial Inclusion in Sub-Saharan Africa: The Moderating Role of Social Networks. Journal of African Business, 19, 361-384.

Bonham, C., \& Wiemer, C. (2013). Chinese Saving Dynamics: The Impact of GDP Growth and the Dependent Share. Oxford Economic Papers, 65, 173-196.

Braun, R. A., Ikeda, D., \& Joines, D. H. (2009). The Saving Rate in Japan: Why it has Fallen and Why it will Remain Low. International Economic Review, 50, 291-321.

Calderón, C., \& Liu, L. (2003). The Direction of Causality between Financial Development and Economic Growth. Journal of Development Economics, 72, 321334.

Cameron, A. C., \& Miller, D. L. (2015). A Practitioner's Guide to Cluster-Robust Inference. Journal of Human Resources, 50, 317-372.

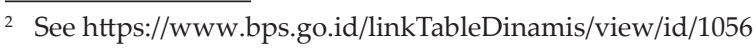


Choi, H., Lugauer, S., \& Mark, N. C. (2017). Precautionary Saving of Chinese and US Households. Journal of Money, Credit and Banking, 49, 635-661.

Cohn, R. A., \& Kolluri, B. R. (2003). Determinants of Household Saving in the G-7 Countries: Recent Evidence. Applied Economics, 35, 1199-1208.

Curtis, C. C., Lugauer, S., \& Mark, N. C. (2017). Demographics and Aggregate Household Saving in Japan, China, and India. Journal of Macroeconomics, 51, 175-191.

Demirguc-Kunt, A., Klapper, L., Singer, D., \& Van Oudheusden, P. (2015). The Global Findex Database 2014: Measuring Financial Inclusion around the World. The World Bank.

Demirguc-Kunt, A., Klapper, L., Singer, D., Ansar, S., \& Hess, J. (2018). The Global Findex Database 2017: Measuring Financial Inclusion and the Fintech Revolution. The World Bank.

Deuflhard, F., Georgarakos, D., \& Inderst, R. (2019). Financial Literacy and Savings Account Returns. Journal of the European Economic Association, 17, 131-164.

Domar, E. D. (1946). Capital Expansion, Rate of Growth, and Employment. Econometrica, Journal of the Econometric Society, 137-147.

Domar, E. D. (1947). Expansion and Employment. The American Economic Review, 37, 34-55.

Evans, O. (2018). Connecting the Poor: The Internet, Mobile Phones and Financial Inclusion in Africa. Digital Policy, Regulation and Governance, 20, 568-581.

Finlay, R., \& Price, F. (2015). Household Saving in Australia. The BE Journal of Macroeconomics, 15, 677-704.

Fisher, P. J., \& Hsu, C. (2012). Differences in Household Saving between Nonhispanic White and Hispanic Households. Hispanic Journal of Behavioral Sciences, 34, 137-159.

Freestone, O., Gaudry, D., Obeyesekere, A., \& Sedgwick, M. (2011). The Rise in Household Saving and its Implications for the Australian Economy. Economic Round-up, 2, 61.

Fulford, S. L. (2015). The Surprisingly Low Importance of Income Uncertainty for Precaution. European Economic Review, 79, 151-171.

Giavazzi, F., \& McMahon, M. (2012). Policy Uncertainty and Household Savings. Review of Economics and Statistics, 94, 517-531.

Grigoli, F., Herman, A., \& Schmidt-Hebbel, K. (2018). Saving in the World. World Development, 104, 257-270.

Guin, B. (2017). Culture and Household Saving. ECB Working Paper 2069.

Harris, M. N., Loundes, J., \& Webster, E. (2002). Determinants of Household Saving in Australia. Economic Record, 78, 207-223.

Harrod, R. F. (1939). An Essay in Dynamic Theory. The Economic Journal, 49, 14-33.

Hatzinikolaou, D., \& Tsoka, A. (2016). Modeling and Estimating the Effects of Institutional Variables on a Pay-as-you-go Social Security System and on Household Saving. Public Finance Review, 44, 589-609.

Heckman, S. J., \& Hanna, S. D. (2015). Individual and Institutional Factors Related to Low-income Household Saving Behavior. Journal of Financial Counseling and Planning, 26, 187-199.

Ho, S. Y., \& Iyke, B. N. (2018). Finance-growth-poverty Nexus: A Re-assessment of the Trickle-down Hypothesis in China. Economic Change and Restructuring, 51, 221-247. 
Horioka, C. Y., \& Watanabe, W. (1997). Why Do People Save? A Micro-analysis of Motives for Household Saving in Japan. The Economic Journal, 107, 537-552.

Hua, T. X., \& Erreygers, G. (2019). Applying Quantile Regression to Determine the Effects of Household Characteristics on Household Saving Rates in Vietnam. Journal of Asian Business and Economic Studies.

Jongwanich, J. (2010). The Determinants of Household and Private Saving in Thailand. Applied Economics, 42, 965-976.

Karp, N., \& Nash-Stacey, B. (2015). Technology, Opportunity \& Access: Understanding Financial Inclusion in the US. BBVA Research paper, (15/25).

Kazarosian, M. (1997). Precautionary Savings-A Panel Study. Review of Economics and Statistics, 79, 241-247.

Ky, S., Rugemintwari, C., \& Sauviat, A. (2018). Does Mobile Money Affect Saving Behaviour? Evidence from a Developing Country. Journal of African Economies, 27, 285-320.

Le Blanc, J., Porpiglia, A., Teppa, F., Zhu, J., \& Ziegelmeyer, M. (2016). Household Saving Behavior in the Euro Area. International Journal of Central Banking, 12, 15-69.

Lenka, S. K., \& Barik, R. (2018). Has Expansion of Mobile Phone and Internet Use Spurred Financial Inclusion in the SAARC Countries? Financial Innovation, 4, 5.

Lugauer, S., Ni, J., \& Yin, Z. (2019). Chinese Household Saving and Dependent Children: Theory and Evidence. China Economic Review, 57, 101091.

McKinsey Global Institute. (2016). Digital Finance for All: Powering Inclusive Growth in Emerging Economies. McKinsey \& Company

Mody, A., Ohnsorge, F., \& Sandri, D. (2012). Precautionary Savings in the Great Recession. IMF Economic Review, 60, 114-138.

Olowofeso, E. O., Adeleke, A. O., \& Udoji, A. O. (2015). Impact of Private Sector Credit on Economic Growth in Nigeria. CBN Journal of Applied Statistics, 6, 81101.

Ozili, P. K. (2018). Impact of Digital Finance on Financial Inclusion and Stability. Borsa Istanbul Review, 18, 329-340.

Samantaraya, A., \& Patra, S. K. (2014). Determinants of Household Savings in India: An Empirical Analysis Using ARDL Approach. Economics Research International, 2014.

Sassi, S., \& Goaied, M. (2013). Financial Development, ICT Diffusion and Economic Growth: Lessons from MENA Region. Telecommunications Policy, 37, 252-261.

Setiawan, S. (2015). Financial Depth and Financial Access in Indonesia. Journal of Indonesian Economy \& Business, 30.

Silva, I. D. (2012). Evaluating the Impact of Microfinance on Savings and Income in Sri Lanka: Quasi-experimental Approach Using Propensity Score Matching. Margin: The Journal of Applied Economic Research, 6, 47-74.

Solow, R. M. (1956). A Contribution to the Theory of Economic Growth. The Quarterly Journal of Economics, 70, 65-94.

Steinert, J. I., Zenker, J., Filipiak, U., Movsisyan, A., Cluver, L. D., \& Shenderovich, Y. (2018). Do Saving Promotion Interventions Increase Household Savings, Consumption, and Investments in Sub-Saharan Africa? A Systematic Review and Meta-analysis. World Development, 104, 238-256. 
Strauss, J., Witoelar, F., \& Sikoki, B. (2016). The Fifth Wave of the Indonesia Family Life Survey (IFLS5): Overview and Field Report. RAND, Santa Monica.

Ummah, B. B., Nuryartono, N., \& Anggraeni, L. (2015). Analisis Inklusi Keuangan dan Pemerataan Pendapatan di Indonesia. Jurnal Ekonomi dan Kebijakan Pembangunan, 4, 1-27.

Zhuk, M. (2015). Macroeconomic Determinants of Household Savings in Ukraine. Economics and Sociology, 8, 41-54. 


\section{APPENDIX}

\section{Table A1.}

\section{Variable Description}

This table shows the questions used to solicit responses from Indonesian households. These questions are obtained from the IFLS5 Questionnaire.

\begin{tabular}{|c|c|}
\hline Variable & Question in IFLS \\
\hline Log savings & What is total value of $[\ldots]$ at present? \\
\hline Share of savings & What is total value of $[\ldots]$ at present? \\
\hline Head of household does not have access to the internet & Where do you get internet access? \\
\hline Head of household only has public internet access & Where do you get internet access? \\
\hline Head of household has private internet access & Where do you get internet access? \\
\hline No one in the household has private internet access & Where do you get internet access? \\
\hline Private internet only accessed by head of household & Where do you get internet access? \\
\hline $\begin{array}{l}\text { Private internet only accessed by household members } \\
\text { other than the head of the household }\end{array}$ & Where do you get internet access? \\
\hline $\begin{array}{l}\text { Private internet jointly accessed by head of the } \\
\text { household and household members }\end{array}$ & Where do you get internet access? \\
\hline $\begin{array}{l}\text { Saving's decision determined by head of the household } \\
\text { only }\end{array}$ & $\begin{array}{l}\text { In your household, who makes decisions } \\
\text { about [Mopey for monthly saving] }\end{array}$ \\
\hline $\begin{array}{l}\text { Saving's decision determined by the head of } \\
\text { households' spouse only }\end{array}$ & $\begin{array}{l}\text { In your household, who makes decisions } \\
\text { about [Mopey for monthly saving] }\end{array}$ \\
\hline $\begin{array}{l}\text { Saving's decision determined by the head of household } \\
\text { and their spouse }\end{array}$ & $\begin{array}{l}\text { In your household, who makes decisions } \\
\text { about [Mopey for monthly saving] }\end{array}$ \\
\hline Saving's decision determined by other members & $\begin{array}{l}\text { In your household, who makes decisions } \\
\text { about [Mopey for monthly saving] }\end{array}$ \\
\hline Log total assets & What is total value of $[\ldots]$ at present? \\
\hline Log total yearly earnings & $\begin{array}{l}\text { What were the total earnings of }[\ldots] \text { in the last } \\
\qquad 12 \text { months? }\end{array}$ \\
\hline Log head of households' yearly earnings & $\begin{array}{l}\text { What were the total earnings of }[\ldots] \text { in the last } \\
\qquad 12 \text { months? }\end{array}$ \\
\hline Log spouse head of households' yearly earnings & $\begin{array}{l}\text { What were the total earnings of }[\ldots] \text { in the last } \\
\qquad 12 \text { months? }\end{array}$ \\
\hline Head of households' years of education & $\begin{array}{l}\text { - Highest level of schooling attended by HHM } \\
\text { - Highest grade ever completed by HHM }\end{array}$ \\
\hline Spouse of head of households' years of education & $\begin{array}{l}\text { - Highest level of schooling attended by HHM } \\
\text { - Highest grade ever completed by HHM }\end{array}$ \\
\hline Head of households' sex & Sex \\
\hline Head of households' age & Age now \\
\hline Spouse of head of households' age & Age Now \\
\hline Household size & Still living in household \\
\hline Number of working household members & Still living in household \\
\hline Head of households' employment status & $\begin{array}{l}\text { Which category best describes the work that } \\
\text { you do? }\end{array}$ \\
\hline Spouse of head of households' employment status & $\begin{array}{l}\text { Which category best describes the work that } \\
\text { you do? }\end{array}$ \\
\hline Distance to the nearest Bank Rakyat Indonesia (BRI) & $\begin{array}{l}\text { How many kilometres is }[\ldots] \text { from the } \\
\text { community center to this institution? }\end{array}$ \\
\hline
\end{tabular}


Table A1.

Variable Description (Continued)

\begin{tabular}{|c|c|}
\hline Variable & Question in IFLS \\
\hline Distance to the nearest Bank Perkreditan Rakyat (BPR) & $\begin{array}{l}\text { How many kilometres is }[\ldots] \text { from the } \\
\text { community center to this institution? }\end{array}$ \\
\hline Distance to the nearest Village Credit Institution (LKD) & $\begin{array}{l}\text { How many kilometres is }[\ldots] \text { from the } \\
\text { community center to this institution? }\end{array}$ \\
\hline Distance to the nearest Village Cooperative unit (KUD) & $\begin{array}{l}\text { How many kilometres is }[\ldots] \text { from the } \\
\text { community center to this institution? }\end{array}$ \\
\hline Distance to the nearest bank & $\begin{array}{l}\text { How many kilometres is }[\ldots] \text { from the } \\
\text { community center to this institution? }\end{array}$ \\
\hline Distance to the nearest cooperative & $\begin{array}{l}\text { How many kilometres is }[\ldots] \text { from the } \\
\text { community center to this institution? }\end{array}$ \\
\hline Distance to the nearest Baitul Maal wat Tamwil (BMT) & $\begin{array}{l}\text { How many kilometres is }[\ldots] \text { from the } \\
\text { community center to this institution? }\end{array}$ \\
\hline Distance to the nearest sharia bank & $\begin{array}{l}\text { How many kilometres is }[\ldots] \text { from the } \\
\text { community center to this institution? }\end{array}$ \\
\hline BRI's number of services & $\begin{array}{c}\text { What types of services are available at this } \\
\text { institution [...]? }\end{array}$ \\
\hline Banks' number of services & $\begin{array}{c}\text { What types of services are available at this } \\
\text { institution }[\ldots] \text { ? }\end{array}$ \\
\hline Sharia banks' number of services & $\begin{array}{l}\text { What types of services are available at this } \\
\text { institution }[\ldots] \text { ? }\end{array}$ \\
\hline Household lives in urban area & Area: 1. Urban 2. Rural \\
\hline
\end{tabular}


This page is intentionally left blank 